ISSN 0975-3311

Ushus JBMgt, 9, 1 (2010) 61-72

https://doi.org/10.12725/ujbm.16.6

\title{
STRATEGIES FOR ENTREPRENEURSHIP AND INNOVATION - A CASE STUDY
}

\author{
Jyotirmoy Ghosh* \& G. Anjaneya Swamy**
}

\section{ABSTRACT}

Entrepreneurs all over the world have contributed to the economic development of their region. They play a major role not only in organizing production, but in a broader sense, promote the process of economic development. The function of an entrepreneur is to reform or revolutionize the pattern of production by exploiting an invention or more generally an untried technology possibly for producing a new commodity or producing an old one in a new way, by opening up a new source of supply of raw materials or developing a new market. The factor responsible for change, development and ultimately economic growth is innovation. Innovation is the key for not only in developing, new products or (services) for the market but also in stimulating investment interest in the new ventures being created. Innovation is the principal ingredient of entrepreneurship.

Tourism is a smokeless service industry as it consumes less energy and pollutes least compared to any manufacturing industry. United Nations, World Tourism Organization and Department of Tourism Government

* Dept. of Hotel Management, Christ University, E-mail: jyothirmoy.ghosh@christuniversity.in

** School of Management, Pondicherry University, Pondicherry-14. Email: anjaneyag@yahoo.com 


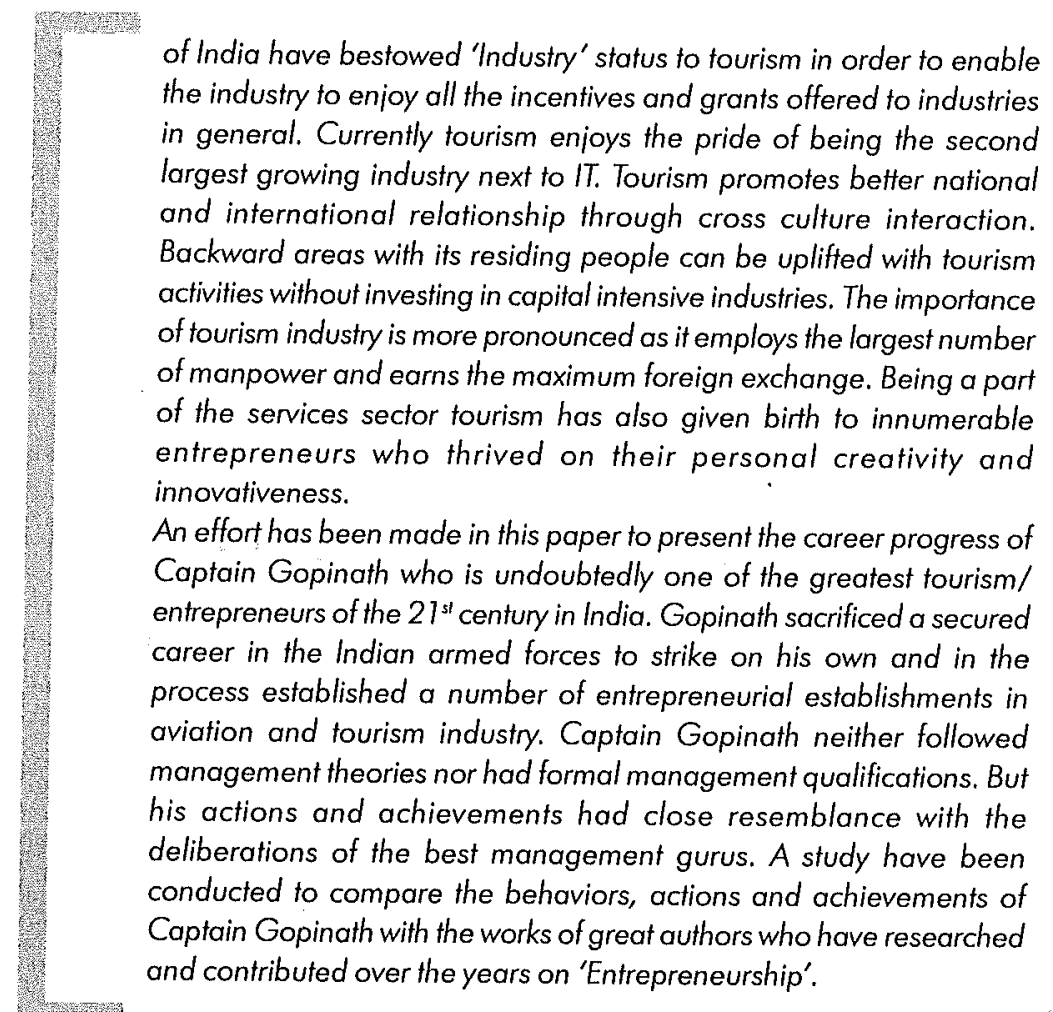

\section{Introduction}

India's one of the most illustrious entrepreneurs of the aviation industry, did not achieve easy success rather his career met with serious challenges. Captain Gorur R lyengar Gopianth, Chairman and Managing Director, Air Deccan certainly had to fight against all odds as he dared to dream and execute many 'first ever in India' projects. Starting almost from scratch Gopinath exhibited all the traits of an entrepreneur and took illustrative innovative decisions to sail from one venture to another. His life and works can be one of the best role model case studies for management students and aspiring entrepreneurs. The best part of the case study is Captain Gopinath is in action as on today executing his entrepreneurial genius in some of his ventures mentioned in the article. 


\section{Career Brief of Captain Gopinath}

A graduate from National Defense Academy, Captain Gopinath served in Indian Army for 8 years. He left army in 1979 where he was 27 years old and ventured into farming. After tasting success as a Seri culturist he moved on to launch his Deccan Aviation, a heli-charter firm. The man gave India the lowest fare airlines, Air Deccan. Recently, he sold his Deccan Aviation to Kingfisher and now launching yet another venture Deccan Cargo. Captain Gopinath is also working on constructing low cost airports. The Karnataka government has shown active interest for setting up low cost airports in Shimoga, Gulbarga and Bidar at a cost of 20 Crore each, compared to over Rs. 300 crore that regular airports cost.

Captain Gopinath, pioneer of low-cost flying in India, has started his second innings in aviation by launching a dedicated air cargo business, branded Deccan 360, in Nagpur. Mr. Gopinath has already invested Rs 125 crore in the cargo venture Deccan Express, and needs to raise an additional Rs 150 crore. The venture would hire about 5,000 people in five years. In the first phase, the company plans to appoint 100 franchisees and each franchisee will hire 10 people. It will fly three Airbus A310 planes and seven smaller ATR planes to connect 17 Indian cities and international destinations like Dubai and Hong Kong.

With not much finance coming to fund his cargo venture due to the slowdown, Mr. Gopinath sold his stake in Kingfisher Airlines to raise funds. The latest International Air Transport Association (IATA) data shows cargo traffic is 12\% above its December 2008 low, but 17\% below the peak early last year. Deccan Cargo has also signed an agreement with the GMR Group for setting up express cargo operations at Delhi and Hyderabad airports, which along with the hub in Nagpur will form an extensive multimodal storage, transportation and delivery network.

Deccan Express Logistics will pitch against established players such as Blve Dart, GATI, TNT Express and First Flight in India's domestic cargo and logistics market. The \$625-million domestic express cargo market is expected to grow at $20 \%$ annually over the next five years.

The tourism entrepreneur from Bangalore has many awards to his credit. The French government has bestowed the award of Character de la legion $d^{\prime}$ Honneur (Knight of the Legion of Honour) on Capt. G.R. Gopinath, 
Chairman, Dir. Deccan. The award is recognition of Capt. Gopinath's contribution to the development of Indo-French Cooperation in the field of aviation. The award was conferred upon Capt. Gopinath by H.E the French Ambassador, Mr. Dominique Girard on Saturday 28 April 2007 at the Alliance Francaise de Bangalore. Captain Gopinath is the recipient of several national awards such as the 'Rajyotsava Award' by the Government of Karnataka. 'Personality of the Decade Award' instituted by KG Foundation; 'Editors Choice Award' by the Indian Express Trade and Tourism Awards and 'Sir M. Visveswaraya Memorial Award' by the Federation of Karnataka Chambers of Commerce and Industry. Many other awards have gone to his credit. Captain Gopinath is a down to earth man who currently lives in Bangalore with his wife and 2 daughters, Pallavi and Krithika.

\section{Captain Gopinath's address to students and entrepreneurs}

To study the driving force of an entrepreneur the best way and perhaps the only way to get the true picture is to get it from the 'horse's mouth'. Captain Gopinath speaks to students and aspiring entrepreneurs with these wise words:

"India today is a country abounding with opportunities and optimism. The 9\% GDP growth rate of the past few years, coupled with rising incomes and progressive liberalization, has inspired a wave of first generation entrepreneurs to the fore. New age entrepreneurs, both small and big, are making a foray into diverse sectors and pioneering new opportunities and potential. You can be an entrepreneur and achieve your dreams regardless of where you are right now. Do make sure you have a vision, a well researched plan in place and stay positive? It also helps to take a long view as you may have to take a step back to survive for the next day.

I often tell people that, we cannot let the fear of stumbling make us give up walking and moving ahead. I have not studied management nor do I follow B-School jargons. I believe in taking risks, pursuing challenges and innovating at every step. I largely rely on my gut instinct which is backed by exhaustive reading and discussions. 


\section{Cause and Effect}

In a business the two most important activities are cost optimization and increasing profit/income. It is critical to study the market, the opportunities to differentiate your product in the market and provide the consumer more reasons to acquire it than ignore it. To identify what you are doing wrong, you have to come clear on your own strengths, weaknesses and objectives. Specify your goals and the course of action you believe will lead to it. You refer to your trading business spread between Mumbai and Gujarat. You need to understand your business space, your competitors and above all your target consumer. Think for yourself. Disengage yourself from what everyone in your industry is doing or saying. Do your own research exhaustively on your market, competition and the product.

\section{Innovate}

Unlock innovation. Start by taking a long, hard look at rules and behaviors inside your organization that might be scuttling innovation in the first place. Don't hesitate to challenge outlined assumptions. Do not restrict innovation only to the business product, work on your processes, structure, business model and even the market. Ask questions like "What if we do this differently?" or "What if we target a different consumer base?" During the course, you can identify processes that will enable you to inch closer to your objective. Look for innovation from diverse and multiple sources. Innovation can stem from employees, partners, suppliers and also consumers, make sure that you are not ignoring any of them.

I was born in a remote village in Karnataka where my father was a school teacher. I studied in a Kannada medium school till class 7 . After graduating from the National Defence Academy I fought in the 1971 Bangladesh war and later served in the Indian Army for eight years. I knew I had to leave my sheltered army life and explore new opportunities but I hadn't figured out what I wanted to do. I took premature retirement in 1978 and with Rs 6,000 in my pocket left for my village with plans to till my ancestral land. That decision turned out to be the turning point of my life. As luck would have it, a dam built on River Hemavathy had submerged our lands in exchange for which the government allotted us 40 acres of barren land which no one in my family wanted, due to its inaccessibility. I decided to live on the land and give it a try. 
With loans from family and friends I started with agriculture which proved to be a constant struggle leading to perpetual debt. I learnt about sericulture and decided to move away from the traditional techniques and adopt modern sericulture practices which are cost effective, environmentally safe and sustainable in the long run. Finally, the gamble paid off, I made profits and was able to pay off my debts. The eco friendly technique of silk farming also earned me the Rolex International Award in 1996.

While there is no recipe for success, you should keep in mind that sometimes innovation is first met with hardship. Many times there is a lot of push back. It is important to remember why you started the business in the first place. If the dream inspires you keep on fighting, if not, it is better to change course. Most importantly, learn to assimilate failure. No failure or disappointment is a closed chapter. It is an invaluable opportunity to rectify errors, and move forward.

\section{Execute}

While planning is important for progress and success. It is execution which becomes the undoing of great plans and strategies. It is critical to motivate your team to identify with your vision and help them pursue and achieve their potential. A good thumb rule is 'Ready, Fire, Aim.' "

Source: Captain Gopinath's address to students of the Department of Management Studies. IIT Madras. 19th August 2007.

\section{Analysis of the innovative moves of Captain Gopinath}

No research on tourism entrepreneurship of India would be complete without the study of Captain Gopinath's Career. His aspirations and tenacity has strong similarity with the works of Professors Howard Stevenson and Jeffrey Timmons (1985), as "The entrepreneur is someone who acts with ambition beyond that supportable by the resources currently, under his control, in relentless pursuit of opportunity." Captain Gopinath could channelize his visions through marketable products that had value for customers based on the needs of time. He understood the enormous demand of, low cost airlines and subsequently low cost airports, the middle class, upward mobile, Indian citizen had, and thus had to be satisfied. The decision of giving the 
common man of India a chance to fly in aircraft was undoubtedly 'the bright idea' that is recommended by Peter F. Drucker (1985) as the strongest and outnumbers all other categories of source of innovative opportunities taken together. Gopinath knew among the teeming 1.17 billion population of India $28 \%$ was urban and $72 \%$ was rural and a sizeable number of the rural population was affluent. He had a dream to provide the entire earning Indian citizens an opportunity to fly at a marginal profit (or with out profit) pricing. His strategy was to mop up money in mass market. Gopinath was unknowingly motivated by the aspects of Social Theory and Entrepreneurship Innovation Theory both preached by Joseph Schumpeter $(1911-1950)$ and others who stated entrepreneurship as a social process and entrepreneurs as social innovators who use the process to shatter the status quo through new combinations of resources and new methods of commerce. Thus India's first economy airlines Deccan Aviation was launched with unbelievable ticket rates with self e- ticket purchasing option and point of sales at Indian Post Offices. These were all 'first time in India' brilliant innovative ideas and can be compared to Drucker's proverbial "The Bright Idea" as advocated in his bestseller Innovation and Entrepreneurship Practice and Principles. According to Drucker innovations based on a bright idea outnumber all other categories of sources of innovation taken together.

\section{Display of motivational factors}

When Captain Gopinath left his secured army life to do something on his own he was clearly motivated by 'need for achievement' (nAch) which David Mc Clelland (1961-1965) expressed as the greatest need responsible for driving entrepreneurs. So when Gopinath became restless in his secured central government army job and felt the burning desire to achieve more for personal recognition and better financial gain he displayed his first urge for successful entrepreneurial career.

When the dam construction compelled to flood and submerge Captain Gopinath's ancestral land and the government offered a barren land as the compensation the 'push and pull theory of motivation' started playing its role in his life. When all the relatives did not want to associate themselves with the barren land Gopinath had to take up the challenge of agricultural operations there; being 'pushed' to circumstances. But' he was nurturing the inherent desire for entrepreneurial activities in life and thus was motivated by the 'pull' factor also. 
During his agricultural pursuit for six years Captain Gopinath slept under a thatched roof and tried to make living by growing bananas, cereals, coconuts, and vegetables in the government provided land when his ancestral land was eaten up by a dam. It was in 1985 that he switched to silkworm rearing. And he had to wait for four more years to see some success when he could make moderate profits. Gopinath's innovative decision of switching over to sericulture when mainstream agriculture failed and not deciding to quit also speaks of changes of perception, new knowledge and incongruities that Peter F. Drucker (1985) prescribed as sources for innovation.

Ten long years of toil in a completely new area of agro based activities, and it didn't end with farming. When he launched Deccan Aviation, it took Captain Gopinath four years to get one helicopter on lease. At every step he faced new bundle of challenges whether they emanated from government controls, competition or something else. His first Air Deccan flight caught fire and everyone wrote his company off. But he says that he's been an optimist who always refused to give up. He faced all challenges head on, to give India Air Deccan that boasts about fastest aircraft turn around time, cost efficiency, wide connectivity and ticketing access.

\section{Execution of creativity, innovation and the passion to carry on}

David H. Holt (1992) and Peter F. Drucker (1985) both strongly expressed that creativity is the brilliant spark that entrepreneurs are triggered with. Entrepreneurs can see what common people cannot see. In a way they are far ahead of their times. This creativity gives them a vision which forms a beacon to show a new path to the entrepreneurs. Vision keeps the entrepreneur inspired and focused. Captain Gopinath points out that the most important inspiration comes from one's own vision. One doesn't need inspiration from outside; it has to come from within. Without a clear vision and resolute focus one can easily lose the steam. Some believe in tried out management mantras and well laid out strategies. Captain Gopinath reveals that he does not follow cut out management formulas instead he trusts his own instincts, does his own research, and makes his own judgments. He's another example that one doesn't need to have degrees from premier institutes or high tech training to strike it big as an entrepreneur. 


\section{Burning Desire to innovate}

David H. Holt (1992), Joseph Schumpeter(1950), Gifford Pinchot(1985), Peter F. Drucker(1985), Karl H. Vesper(1992) and all other stalwarts contributing to subject of entrepreneurship is of the opinion creativity is the prerequisite to innovation and innovation is the driving force for entrepreneurial actions. Until Captain Gopinath started using radically different farming techniques that what other farmers were commonly using, his farming venture wasn't taking off - Innovation took his farming to a new level. He even got prestigious Rolex award for adopting organic farming techniques. Making the common man of India take affordable air trips; selling food and beverage on board at low cost and not making them compulsory to make the ticket expensive; direct access to airline tickets online with a print out; tying up with all post offices for Air Deccan tickets, venturing into low cost airports and low cost cargo carriers - his innovative ideas are endless. The dominant urge that prevailed in Gopinath's life was focused around social entrepreneurship and not really for blunt economic gains. Exponents of the social entrepreneurship theory as Immanuel Wallerstien (1974) and Joseph Schumpeter (1934) expressed the entrepreneurs are motivated by social causes and fulfilling long cherished dreams of the people. Almost all the ventures as low cost airlines, low cost airports, and economy air cargo - the common aim was benefit to the mass.

Captain Gopinath stresses that one should pursue his passion and never let fear of failing come in the way. The problems will come and failures are unavoidable but having single minded focus, determination and ability to assimilate failures is the only way forward, he believes. From army, farming and deals, to aviation, Gopinath has had one dream that is to make a difference and in spite of all odds he continues to pursue that.

\section{Understanding of Venture Life Cycle}

Captain Gopinath sold off Air Deccan as he understood the venture life was coming to an end and definitely it needed major monetary inputs and a total turnabout in its strategic management and wisely allowed Kingfisher Airlines acquisition of his company. With the sale proceeds he could start yet another venture Deccan Cargo with a new venture life.

Robert D. Hisrich and Michael P. Peters' works on 'Growth cycle of a New Venture' with relevant graph as depicted in the book "Entrepreneurship" 
(Indian reprint 2002) is being sited to compare it with Air Deccan's tenure. The authors explain all new ventures go through a cyclic pattern of four stages that can be expressed briefly as the following:

1) Start - up: The first few years of entrepreneurship business fetches little revenue and offer slender growth.

2) Early growth: At this stage the revenue increases considerably and the firm attains stability.

3) Rapid growth: This stage according to the learned authors largely depends on the individual entrepreneur. The enterprise, the drive and the innovative spirit of the entrepreneurs can take them through this stage of rapid growth marked by increase of market share, increased revenue growth, and expansion of business. According to Robert D. Hisrish and Michael P. Peters not all ventures enters into the rapid growth phase. Many will continue to exist at some satisfying level of sales with little or no growth.

4) Maturity: At this stage competition increases, the costs go up and the sales are steady. The entrepreneurs should realize time has come for starting one more cycle. The experts recommend to cut costs, use promotional techniques and by and far use innovations to do something new, or sell off the venture for a good price and start one more new.

Deccan Aviation's venture life cycle surprisingly followed the above mentioned course. During start up Captain Gopinath had crisis, financial problems, bureaucratic hurdles but made operative profits to continue. At the early growth stage he introduced his innovations to almost everything, as logo design of the 'common man', a la carte food \& beverage during flight, direct access to e-ticketing, recruiting retired pilots of Air India \& Indian Airlines - all that actually made his company grow. Rapid growth period was very evident as there was a rush for cheap air tickets all over the country and everybody wanted to travel Air Deccan. The other airlines companies had no alternative but to start selling economy tickets proving the trend setting power of Captain Gopinath's Deccan Aviation. 


\section{Growth Cycle of a New Venture}

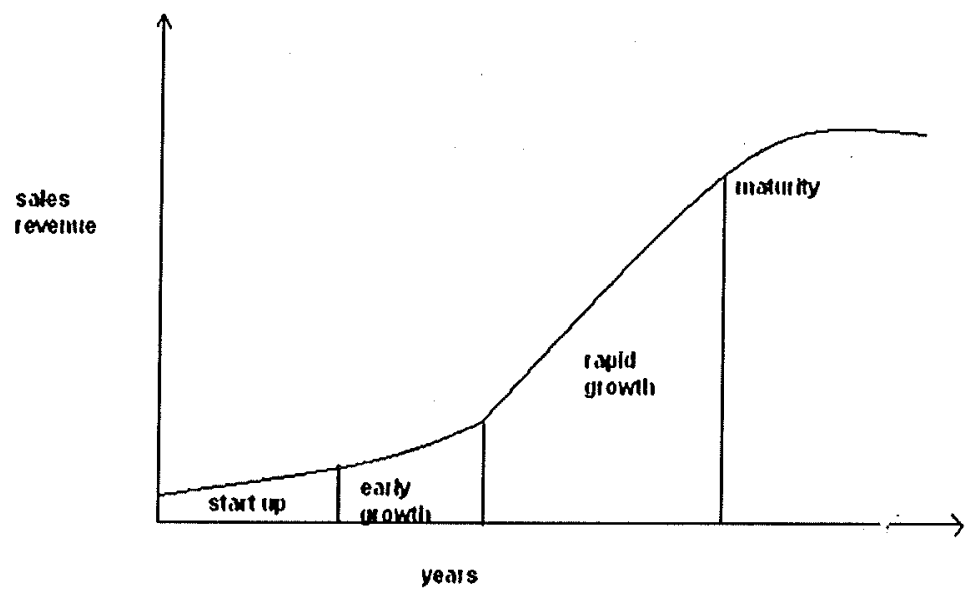

Source: Adapted from book "Entrepreneurship" by Hisrich Peters. (Indian reprint, 2002). p507

Captain Gopinath could sense that Deccan Aviation was at the maturity level of the venture growth cycle and the growth factor was stagnating and it required additional dose of finance and better access to international market. At the most appropriate time he sold off his shares to Vijay Mallya's Kingfisher Airlines, to initiate one of most interesting merger and acquisition operation, the aviation industry has ever seen.

\section{Conclusion}

Captain Gopinath's move was instinctive and he had little knowledge about the management texts as he himself advocates he never follows management jargons but only his instincts. The entrepreneur over the ages have created new establishments, employed hundreds of people, set trends, built regional and national economies with only one power that springs from one's inner inspiration.

The master tourism entrepreneur of our case study still continue is his pursuits of creating new ventures and setting new trends that many businessmen, eminent authors, scholars and students will draw inspirations from in years to come. 


\section{References}

Adam Smith, (1937) The Wealth of Nations, New York: Random House.(Reprint).

Cooper Chris, Fletcher John, Fyall Alan, Gilbert David and Wanhill Stephen (2005) Tourism Principles and Practice. Pearson Education Limited. Essex. U.K. ed.3.

Drucker Peter F (1985) Innovation and Entrepreneurship - Practice and Principles. Harper \& Row Publishers. New York.

Drucker Peter F. Beyond the Information Revolution. Atlantic Monthly. (October 1999) pp 47-57.

G. Pinchot, (1985) Intrapreneuring. New York. Harper \& Row.

Hisrich Robert D., Peters Michael P. (1998) Entrepreneurship, Irwin McGraw-Hill, USA.

Holt David H. (1998) Entrepreneurship - New Venture Creation. Indian Reprint.

J. Schumpeter (1934) The Theory of Economic Development Harvard University Press.

J. Naisbitt (1982) Megatrends: Ten New Directions Transforming our Lives Warner Books. New York pp 35-36.

http://en.wikipedia.org/wiki/g.r.gopinath.

Rao Smitha Tourism plans go full throttle. The Times of India, Bangalore, Thursday, January 11, 2007, p 5. 